\title{
GDP rate in the European Union: simulations based on panel data models
}

\author{
Mihaela Simionescu \\ Institute for Economic Forecasting of the Romanian Academy, \\ Bucharest, Romania \\ mihaela_mb1@yahoo.com
}

\author{
Kamil Dobeš \\ Tomas Bata University in Zlin \\ Czech Republic \\ dobes@fame.utb.cz \\ Ivan Brezina \\ Pan-European University \\ Bratislava, Slovakia \\ brezina.ivan@yahoo.com \\ Andrea Gaal \\ Pan-European University \\ Bratislava, Slovakia \\ gaal.a@gmail.com
}

Abstract. The objective of this paper is to provide more details regarding the evolution of real GDP growth in the countries of the European Union (EU-28) in the period from 2004 to 2015 based on a panel data approach. According to the estimations based on some dynamic panel data models, an any increase in the real GDP rate in the previous period by one percentage point, the real GDP rate in the current period will increase by 0.3 percentage points up to 0.5 percentage points. According to the Fixed Effects Model with time and individual effects, the real GDP growth is explained by the employment. According to simulations for 2016 and 2017 based on Dynamic Model and the Fixed Effects Model, the last model predicting higher GDP rates with respect to dynamic models. The result of this study is the estimation of the real GDP rates in EU-28 countries, which are based on presented econometrics models. The annual average of employment as the main factor of GDP growth is taken into account.

Keywords: GDP rate, employment, panel data, Dynamic Model, Fixed Effects Model

JEL Classification: C150, C530 


\section{INTRODUCTION}

A deep economic instability was observed in the last 10 years in some EU countries. The economic issues were met not only on short-term, but also on long run: high unemployment, low economic growth, a fast population ageing. Starting from these issues, in this paper we focused on the economic growth in all of the EU countries using a panel data approach.

The economic growth is a macroeconomic variable that is connected with many other variables. In literature reviews many types of econometric models are being proposed. The models used are, e.g. univariate autoregressive (AR) and multivariate vector autoregressive (VAR) models (Cross and Poon 2016; Ciccarelli et al. 2016), Bayesian vector autoregressions (BVARs) model (Carriero et al. 2015) or Matutinović et al. (2016) who have developed a system model of autocatalytic growth and development.

In this study, the Panel Data Approach is applied, i.e. the real GDP rate is explained by using Dynamic and Fixed Effects Models. The real GDP rate is analyzed using the correlation with employment.

The relationship between GDP growth and unemployment was analyzed and formulated in Okun's Law, which is well-known in economic theory and is applied in/to many countries. One example can be found in (Caraiani, 2012), for example. One of the key elements in this study is that the employment factor directly correlates with and has a major impact on real GDP growth. It is assumed that not only employment, but GDP growth in previous periods affect the level of current real GDP growth.

This paper seeks to confirm this theory by analyzing economic growth factors in all the EU countries using the Panel Data Approach. This approach has the advantage that many cross-sectional data can be observed during a defined period of time. In contrast to the Cross-Sectional Data Approach, which observes many objects simultaneously, the Panel Data Approach takes into account the dynamics of observed variables. This means that real GDP growth in all the EU countries over more periods of time can be analyzed.

After a brief introduction a short literature review follows. The methodology corresponds to Dynamic Model and Fixed-Effects Model theory. Economic growth is explained for all the countries in the EU-28 over the period 2004-2015 and simulations are conducted for the years 2016 and 2017.

\section{LITERATURE REVIEW. MODELS FOR ECONOMIC GROWTH}

The Solow's neo-classical growth theory indicates that there are two long-run factors determining the economic growth: Population growth and total factor productivity rate. On the other hand, on mediumterm, the savings rate and physical capital accumulation have a positive influence on the GDP rate. In the economic literature, many variables might be considered as engines of the economic growth:

- Human capital is a main source of growth in the endogenous growth model and in the augmented Solow one;

- Foreign direct investment (FDI) has positive effects on GDP, according to Petrakos, Arvanitidis and Pavleas (2007), because FDI intensify benefic spillover effect, production internationalization and trade openness;

- Investment is a key element in neoclassical models and endogenous growth models as Workie (2005) mentioned;

- Openness ensures the exploitation of comparative advantage, knowledge diffusion, technological transfer, increasing scale of economies according to Egger and Larch (2007);

- Stable macroeconomic policies and conditions have some important characteristics or benefits: Sustainable budget deficit, low departure of real exchange rate from the equilibrium point, low and predictable inflation rates;

- Initial level of income, which is important for transition countries; 
- Political issues like civil and political freedom, political instability and political regime.

- Liberalization and Structural reforms for market-oriented countries;

- Institutional framework that is assessed using several indicators: Property rights, Expropriation risk, values of country risks or customer satisfaction in institutions government repudiation of contracts, according to Belás et al. (2016).

The economic theory showed a positive correlation between GDP rate and employment. If economic growth is analyzed in more states, Chubrik (2005) proposes that a separate regression should be run for each country when there are high correlations among regressors. However, recent studies recomanded that the Panel Data Approach should describe GDP growth rate in more countries such as ones in the European Union. The main advantages of panel data lie in the fact that they comprise more informative data, show more variability, display a higher number of degrees of freedom, less co-linearity between variables and more efficiency. Other possibility of explaining economic growth is by using a theory of endogenous fiscal policy and growth which was used in the study of Barseghyan and Battaglini (2016). They state that the growth depends on public investment, private investment and labor supply. A fiscal policy is determined through the legislative bargaining.

In the study by Tas, Hepsen and Onder (2013), the gross domestic product in EU countries and several candidates during 2002-2012 is explained in a panel data framework using as regressors: General government gross debt, general government total expenditure, current account balance, gross national savings, inflation (average consumer prices), unemployment rate, general government revenue, population, volume of exports of goods and services, volume of imports of goods and services, total investment. The Population size positively influences economic growth, while unemployment rate and total expenditure have a negative impact on economic growth. Mielcová (2011) or Flek and Mysíková (2015) conducted research on the correlation between factors such as unemployment and economic growth in a country. Ono and Uchida (2016) have researched the effects of population aging on these policies and economic growth from a political economy perspective. They state that a very interesting factor influencing economic growth is the competition between generations regarding public education and public pensions.

Ciftcioglu and Begovic (2008) analyzed the relationship between GDP growth and different economic variables using panel data models for 9 East and Central European Countries during 1995-2003. The selection of the best panel data model is based on F, LR and Hausman tests. Several variables have a positive impact on economic growth: Ratio of budget balance to GDP, ratio of the sum of exports and imports to GDP and share of domestic investment in GDP. On the other hand, inflation rate, its volatility and ratio of the stock of external debt to GDP has a negative on real GDP rate. For South-East European countries, Trpkova and Tashevska (2011) developed a Panel Data Analysis to determine the factors that generate economic growth. 7 states were chosen (Romania, Bulgaria, Albania, Bosnia and Herzegovina, Serbia, Macedonia and Croatia) during 1995-2007 and the economic growth was generated by inflation rate, exchange rate, current account/GDP, population growth, general government balance, large scale privatization, and general government expenditure and price liberalization.

Patillo et al. (2004) used a large panel data series for 61 developing countries in the period 1969-1998 and they showed the increase in "external indebtedness" negatively affected economic due to of the adverse effects on physical capital accumulation and total factor productivity growth.

Furceri and Karras (2008) studied the impact of changes in taxes on economic growth for 26 countries of OECD using a panel data approach in the period 1965-2007. The increase in taxes with 1 percent generated a decrease in per capita real GDP with a value between -0.5 percent and -1 percent. The increase in taxes on goods and services or social security contributions has a more intense impact on per capita real GDP than the income tax increase. 
A Panel Data Analysis was run for ASEAN countries by Hussin and Saidin (2012) who evaluated the impact on GDP of the following variables: Openness, foreign direct investment and gross fixed capital formation. A pooled model, a fixed effects model and a random effects model are estimated over the period from 1981 to 2008. All the macroeconomic variables are positively correlated with GDP, but the results of Panel Data Models indicated that for all four ASEAN countries (Thailand, Philippines, Malaysia and Indonesia) FDI is not correlated with GDP.

Adhikary (2011) measured a positive correlation between economic growth, capital formation foreign direct investment (FDI) and trade openness in the US countries. Hoang, Wiboonchutikula and Tubtimtong (2010) studied the impact of FDI on the economic growth in Vietnam regions by employing a Panel Data Model in the period from 1995 to 2006. The authors showed that FDI had a significant and positive impact on the economic growth in Vietnam.

As Cross and Poon (2016) state in their study, the expected performance of Australian key macroeconomic variables, such as real GDP growth, CPI inflation and a short-term interest rate, can be improved by whether the incorporating time variation and fat-tails into a suit of popular univariate and multivariate Gaussian distributed models. According to their results, it is evident that the VAR with the proposed features provides the best interest and inflation forecasts. Moreover, a simple rolling window AR with Student's-t errors provides the most accurate GDP forecasts (Bratu, 2012).

Higgins et al. (2016) have used the Bayesian VAR model when studying economic growth of China. This one has a superior out-of-sample performance in forecasting the real GDP growth. They state that the model can be used to provide policy projections under different policy scenarios. Based on this model, they suggest that a future GDP growth path will be of the L-shape rather than the U-shape.

\section{METHODOLOGY}

We start our research from a regression model based on spatial and temporal date (pooled ordinary least squares- POLS) without using fixed or random effects from panel techniques:

$$
y_{i t}=\beta_{0}+\sum_{j} \beta_{j} \cdot X_{j i t}+\varepsilon_{i t}
$$

$y_{i t}$ - dependent variable for individual unit $\mathrm{i}$ and at time $\mathrm{t}$

$X_{j i t}$ - the regressor " $\mathrm{j}$ " for individual unit $\mathrm{i}$ and at time $\mathrm{t}$

$\beta_{0}$ - constant (common for all individual units)

it - errors

$\mathrm{i}=1,2, \ldots, \mathrm{N} ; \mathrm{t}=1,2, \ldots, \mathrm{T}$

This general model will be transformed for estimating the parameters using the fixed-effects panel techniques that test the existence of individual effects. Considering a specific particularity of each individual unit that is constant in time, the unobserved characteristics are modeled as fixed-effects included in different values of $\beta_{0 i}$ for each individual unit. These individual effects show the individual units characteristics that suppose to be constant in the mentioned period that has impact on the dependent variable. Therefore, the unobserved heterogeneity is controlled under the assumption that it is constant in time and, eventually, correlated with regressors. The form of One-Way Fixed Effects Model is:

$$
y_{i t}=\beta_{0 i}+\sum_{j} \beta_{j} \cdot X_{j i t}+\varepsilon_{i t}
$$


$y_{i t}$ - dependent variable for individual unit $\mathrm{i}$ and at time $\mathrm{t}$

$X_{j i t}$ - the regressor " $\mathrm{j}$ " for individual unit $\mathrm{i}$ and at time $\mathrm{t}$

$\beta_{0 i}$ - unobserved individual effect (constant in time for each individual unit)

$\varepsilon_{i t}$ - errors

$\mathrm{i}=1,2, \ldots, \mathrm{N} ; \mathrm{t}=1,2, \ldots, \mathrm{T}$.

The model could be extended for including the fixed-effects in time (Two-Way Fixed Effects Model):

$$
y_{i t}=\beta_{0 i}+\gamma_{i}+\sum_{j} \beta_{j} \cdot X_{j i t}+\varepsilon_{i t}
$$

- fixed effects in time.

The impact of time passage is put into evidence by changes in economic policies, the economic crisis influence or the economic relancement in each individual unit.

The Random Effects Model considers the model constant as a random variable of average $\beta_{0}$, but the differences between individual units are random deviations from the constant mean $\beta_{0}$ :

$$
\beta_{0 i}=\beta_{0}+\varepsilon_{i}
$$

In the case of random effects model, the errors are determined as:

$$
u_{i t}=\varepsilon_{i}+e_{i t}
$$

$\varepsilon_{i}$ - error that is specific to individual unit $i$

$e_{i t}$ - random error.

The demeaning transformation in panel data generates the problem of unobserved heterogeneity. The dynamic panel models make the first differencing to remove the unobserved heterogeneity. A partial adjustment mechanism is ensured by the lagged variable or lagged variables in the model. The demeaning procedure generates a regressor which is not distributed independently of the error. If the explanatory variables are correlated with the lagged dependent variable, the coefficients are biased. The Fixed-Effect Model has the problem of Nickell bias.

This bias appears even if the errors are independent and identically distributed. In order to solve this problem, the first differences of the initial model are considered. If a single explanatory variable and a lagged dependent variable $\mathrm{Y}$ are taken, we consider the following model:

$$
y_{i t}=\beta_{0}+\rho \cdot y_{i, t-1}+\beta_{1} \cdot X_{i t}+u_{i}+\varepsilon_{i t}
$$

$X_{i t}$ - exogenous regressors

$y_{i t}$ - dependent variable

$u_{i}$ - unobserved individual effect

$\varepsilon_{i t}$ - error. 
The construction of the model in first difference will eliminate the constant and the individual effect:

$$
\Delta y_{i t}=\rho \bullet \Delta y_{i, t-1}+\beta_{1} \bullet \Delta X_{i t}+\Delta \varepsilon_{i t}
$$

In this case we still have correlation between disturbances and the lagged dependent variable.

We may build instruments for the lagged dependent variable from the $2^{\text {nd }}$ and the $3^{\text {rd }}$ lag. If the error is i.i.d., then the lags are correlated with the lagged dependent characteristic, but it will not be correlated with the composite error term.

Let consider the equations:

$$
\begin{gathered}
y_{i t}=\beta_{0} \bullet X_{i t}+\beta_{1} \bullet W_{i t}+v_{i t} \\
v_{i t}=u_{i}+\varepsilon_{i t}
\end{gathered}
$$

$X_{i t}$ - exogenous regressors

$W_{i t}$ - predetermined and endogenous regressors correlated with $u_{i}$.

The first-differencing equation eliminates the unobserved individual effect, but omitted -variable bias appears.

The Arrelano-Bond (AB) approach and its extension to System GMM (Generalized Method of Moments) is an estimator for the following cases:

- Many individual units and few time periods;

- A linear and functional relationship between variables;

- One left-hand dynamic variable;

- Not strictly exogenous right-hand variables;

- Fixed individual effects that suppose unobserved heterogeneity;

- Autocorrelation and homoskedasticity within individual units.

The $\mathrm{AB}$ estimator supposes a generalized method of moments problem. It consists in a model built as a system of equations where the instruments corresponding to each equation are different. The possible weakness of $\mathrm{AB}$ estimator is solved by Arrelano-Bond-Blundell-Bond (ABBB) estimator. The lagged levels are in practice poor instruments for the variables in first difference. The new estimator (ABBB one) includes lagged differences and lagged levels. The initial estimator is called difference GMM, but the expanded one is named as System GMM and it supposes supplementary restrictions regarding the initial conditions for generating the dependent variable.

\section{MODELING REAL GDP RATE IN THE EU-28}

The variables that were used in this study refer to: real GDP growth rate (the real economic growth) and the employment (it is computed as annual average). The real GDP growth rate represents the percentage change of GDP on previous year in constant prices. The employed persons work at least one hour for profit and pay in the reference week or they are temporarily absent from this work.

The data corresponding to these variables are collected for the European Union countries (EU-28) during the period 2004-2015. From the very beginning, we have to test if there is any unit root in the data. According to several unit root tests, the panel data are stationary at $5 \%$ level of significance. The evolution 
of real GDP rate for all the countries over 2004-2015 is presented in Figure 1. In 2009, most of the EU-28 states had negative values for real GDP rate. There are few countries with very low values for the economic growth in 2009, among them being: Latvia (-14.8\%), Estonia (-14.7\%), and Cyprus (-14.2\%).

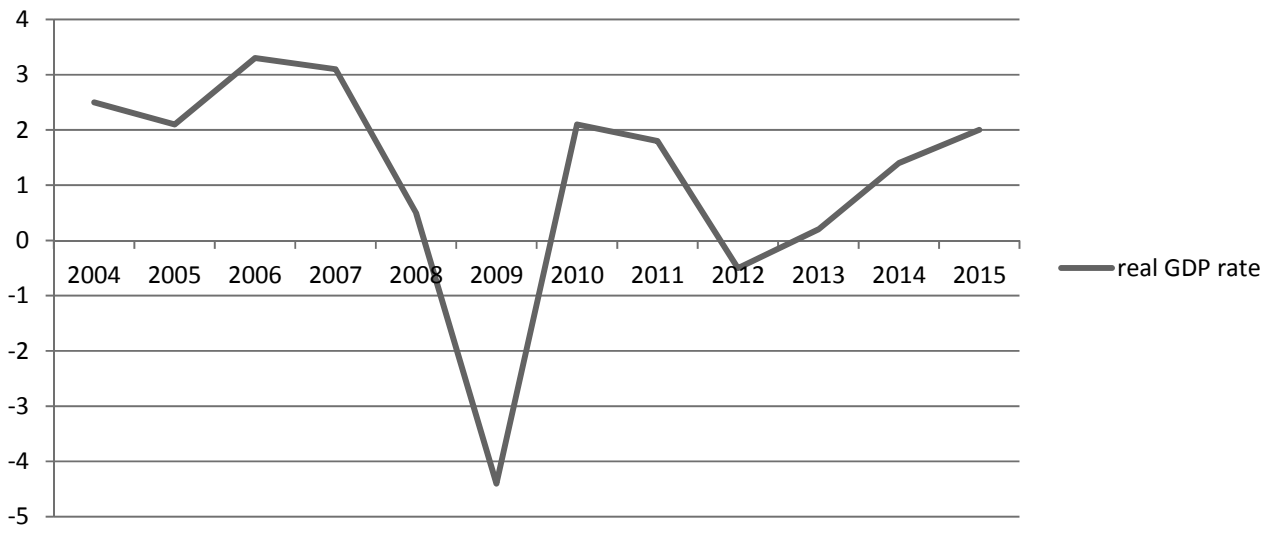

Figure 1. The real GDP rate in the EU-28 in the period 2004-2015

Source: own computations.

The variables that were used in this study refer to: real GDP growth rate (the real economic growth) and the employment (it is computed as annual average). The real GDP growth rate represents the percentage change of GDP on previous year in constant prices. The employed persons work at least one hour for profit and pay in the reference week or they are temporarily absent from this work.

The data corresponding to these variables are collected for the European Union countries (EU-28) during the period 2004-2015. From the very beginning, we have to test if there is any unit root in the data. According to several unit root tests, the panel data are stationary at $5 \%$ level of significance. The evolution of real GDP rate for all the countries over 2004-2015 is presented in Figure 1. In 2009, most of the EU-28 states had negative values for real GDP rate. There are few countries with very low values for the economic growth in 2009, among them being: Latvia (-14.8\%), Estonia (-14.7\%), and Cyprus (-14.2\%).

Table 1

Dynamic panel data models for explaining the real GDP rate evolution in EU-28 over 2004-2015

\begin{tabular}{|c|c|c|c|c|}
\hline \multirow{2}{*}{ Dynamic model } & \multicolumn{3}{|c|}{ Variable } \\
\hline \multirow{3}{*}{ M1 (AB estimator) } & GDP rate & Coefficient & 4 & $\mathrm{z}$ \\
\cline { 2 - 5 } & GDP_rate & 0.402 & 6.98 & 0.000 \\
\cline { 2 - 5 } & constant & 0.9976 & 4.47 & 0.000 \\
\hline \multirow{2}{*}{$\begin{array}{l}\text { M2 (ABBB } \\
\text { estimator) }\end{array}$} & GDP_rate & 0.3887 & 8.85 & 0.000 \\
\cline { 2 - 5 } & constant & 1.0658 & 4.94 & 0.000 \\
\hline
\end{tabular}




\begin{tabular}{|c|c|c|c|c|}
\hline 1 & 2 & 3 & 4 & 5 \\
\hline \multirow{2}{*}{ M3 (AB estimator) } & $G D P_{-}$rate $_{t-1}$ & 0.404 & 2.98 & 0.004 \\
\hline & constant & 0.9864 & 2.83 & 0.006 \\
\hline \multirow{2}{*}{$\begin{array}{l}\text { M4 (ABBB } \\
\text { estimator) }\end{array}$} & $G D P$ rate $_{t-1}$ & 0.3855 & 3.69 & 0.000 \\
\hline & constant & 1.0387 & 3.67 & 0.001 \\
\hline \multirow{3}{*}{ M5 (AB estimator) } & $G D P$ rate $_{t-1}$ & 0.4967 & 6.39 & 0.000 \\
\hline & $G D P_{\text {_rate }}$ r-2 & -0.2543 & -2.49 & 0.020 \\
\hline & constant & 1.2653 & 4.66 & 0.000 \\
\hline \multirow{3}{*}{$\begin{array}{l}\text { M6 (ABBB } \\
\text { estimator) }\end{array}$} & $G D P P_{-}$rate $_{t-1}$ & 0.4429 & 9.91 & 0.000 \\
\hline & $G D P_{-}$rate $_{t-2}$ & -0.276 & -2.86 & 0.004 \\
\hline & constant & 1.4549 & 6.20 & 0.000 \\
\hline \multirow{3}{*}{ M7 (AB estimator) } & $G D P_{-}$rate $_{t-1}$ & 0.3486 & 5.42 & 0.000 \\
\hline & Year 2009 & -8.2875 & -14.33 & 0.000 \\
\hline & constant & 1.8753 & 7.46 & 0.000 \\
\hline \multirow{3}{*}{$\begin{array}{l}\text { M8 (ABBB } \\
\text { estimator) }\end{array}$} & $G D P$ rate $_{t-1}$ & 0.3539 & 6.72 & 0.000 \\
\hline & Year 2009 & -8.9962 & -13.02 & 0.000 \\
\hline & constant & 1.9065 & 8.29 & 0.000 \\
\hline \multirow{4}{*}{ M9 (AB estimator) } & $G D P$ rate $_{t-1}$ & 0.4754 & 37.96 & 0.000 \\
\hline & $G D P$ rate $_{t-2}$ & -0.2765 & -38.32 & 0.000 \\
\hline & employment $_{t}$ & 0.0000743 & 7.47 & 0.000 \\
\hline & constant & 1.0439 & 12.93 & 0.000 \\
\hline
\end{tabular}

Source: authors' computations.

The null serial correlation for errors in first difference is checked from the second order. After this test is applied, only M4, M6, M7 and M8 models remained valid. All in all, we can state that there are only 6 valid dynamic models for explaining the evolution of the real GDP rate in EU-28 states (M1, M2, M4, M6, M7, and M8).

Table 2

Arrelano-Bond test for null autocorrelation in first-differenced errors

\begin{tabular}{|c|c|c|c|}
\hline Model & Order & z-computed & Prob $>$ Z \\
\hline 1 & 2 & 3 & 4 \\
\hline \multirow{3}{*}{ M3 } & 1 & -2.4102 & 0.017 \\
\cline { 2 - 4 } & 2 & -2.778 & 0.008 \\
\cline { 2 - 4 } & 3 & 1.3765 & 0.1802 \\
\cline { 2 - 4 } & 4 & 2.3862 & 0.019 \\
\hline
\end{tabular}




\begin{tabular}{|c|c|c|c|}
\hline \multirow{4}{*}{ M4 } & 1 & -2.745 & 0.006 \\
\cline { 2 - 4 } & 2 & -2.7578 & 0.006 \\
\cline { 2 - 4 } & 3 & 1.4678 & 0.1534 \\
\cline { 2 - 4 } & 4 & 2.3887 & 0.018 \\
\hline \multirow{4}{*}{ M5 } & 1 & -3.1103 & 0.0019 \\
\cline { 2 - 4 } & 2 & -0.6698 & 0.602 \\
\cline { 2 - 4 } & 3 & 1.410 & 0.162 \\
\hline \multirow{4}{*}{ M6 } & 4 & 1.7543 & 0.0906 \\
\cline { 2 - 4 } & 2 & -3.38 & 0.0006 \\
\cline { 2 - 4 } & 3 & -0.32 & 0.7601 \\
\cline { 2 - 4 } & 4 & 1.1309 & 0.2708 \\
\hline \multirow{4}{*}{ M7 } & 1 & 1.5209 & 0.1303 \\
\cline { 2 - 4 } & 2 & -2.755 & 0.006 \\
\cline { 2 - 4 } & 3 & -2.4471 & 0.016 \\
\cline { 2 - 4 } & 4 & 0.3209 & 0.7602 \\
\hline \multirow{4}{*}{ M8 } & 1 & 1.68 & 0.0938 \\
\cline { 2 - 4 } & 2 & -2.881 & 0.005 \\
\cline { 2 - 4 } & 3 & -2.25 & 0.024 \\
\cline { 2 - 4 } & 4 & 0.031 & 0.97 \\
\hline \multirow{5}{*}{ M9 } & 1 & 1.4708 & 0.1467 \\
\cline { 2 - 4 } & 2 & -3.7065 & 0.0003 \\
\hline & 3 & -0.5974 & 0.5698 \\
\hline & 4 & 1.078 & 0.2984 \\
\hline & & 1.9506 & 0.0603 \\
\hline
\end{tabular}

Source: authors' computations.

An increase in the real GDP rate in the previous period with 1 percentage point brought an increase in the real GDP rate in the actual period by 0.4 percentage points (according to model M1), 0.39 percentage points (according to model M2), 0.38 percentage points (according to model M4), 0.34 percentage points (according to model M7) and 0.35 percentage points (according to model M8). According to M6 mode estimations, an increase in the real GDP rate in the previous period by 1 percentage points determined an increase in the real GDP rate in the actual period by 0.44 percentage points, when the other variables remain constant. Moreover, an increase in the real GDP rate with two years ago by 1 percentage points generated a decrease of the real GDP rate in the actual period by 0.27 percentage points, when the other variables remain constant.

Moreover, we estimated a panel data model with fixed-effects in time and cross-sections using employment in the EU-28 as explanatory variable. The assumptions regarding the errors of the model were not checked and this model was not used in simulations. In the first period, the entire variation in the real GDP is due to changes in GDP. If we start from the third lag, around $97 \%$ of the variation in real GDP rate is due to the changes in this variable and only around $2 \%$ of variation is explained by employment changes. In the first period, $1.118 \%$ of the variation in employment is explained by changes in real GDP rate. Starting from the fourth lag, around 6\% of the variation in employment is due to GDP modifications.

The $\mathrm{p}$-values that correspond to the $\mathrm{F}$ and the Chi-square statistics are 0 , providing strong evidence against the hypothesis that the fixed effects are all equal to each other. This implies unobserved heterogeneity in time and in cross-sections. An increase in employment rate by one unit determined an increase by 0.001 percentage points in the GDP rate. 
The equations for fixed-effect model are the following:

R_GDP_1 $=4.4330+$ PER_EFFECT $-9.0819+0.0013^{*}$ EMPL_1

R_GDP_2 $=7.6581+$ PER_EFFECT $-9.0819+0.00137^{*}$ EMPL_2

R_GDP_3 $=4.6724+$ PER_EFFECT $-9.0819+0.00137^{*}$ EMPL_3

R_GDP_4 $=5.7556+$ PER_EFFECT $-9.08199+0.00137 *$ EMPL_4

R_GDP_5 $=-44.9492+$ PER_EFFECT $-9.08199+0.00137 *$ EMPL_5

R_GDP_6 $=12.0053+$ PER_EFFECT $-9.08199+0.00137^{*}$ EMPL_6

R_GDP_7 $=8.34205+$ PER_EFFECT $-9.08199+0.00137^{*}$ EMPL_7

R_GDP_8 $=2.4866+$ PER_EFFECT $-9.08199+0.00137^{*}$ EMPL_8

R_GDP_9 $=-15.6073+$ PER_EFFECT $-9.08199+0.00137 *$ EMPL_9

R_GDP_10 $=-26.46049+$ PER_EFFECT $-9.08199+0.00137^{*}$ EMPL_10

R_GDP_1 $=8.56626+$ PER_EFFECT $-9.08199+0.00137^{*}$ EMPL_1 1

R_GDP_12 $=-24.8100+$ PER_EFFECT $-9.08199+0.00137^{*}$ EMPL_12

R_GDP_13 $=10.17333+$ PER_EFFECT $-9.08199+0.00137^{*}$ EMPL_13

R_GDP_14 $=11.92443+$ PER_EFFECT $-9.08199+0.00137^{*}$ EMPL_14

R_GDP_15 $=10.76034+$ PER_EFFECT $-9.08199+0.00137^{*}$ EMPL_15

R_GDP_16 $=11.08726+$ PER_EFFECT $-9.08199+0.00137^{*}$ EMPL_16

R_GDP_17 $=4.95570+$ PER_EFFECT $-9.08199+0.00137^{*}$ EMPL_17

R_GDP_18 $=11.1130+$ PER_EFFECT $-9.08199+0.00137^{*}$ EMPL_18

R_GDP_19 $=-1.60819+$ PER_EFFECT $-9.08199+0.00137^{*}$ EMPL_19

R_GDP_20 $=5.11783+$ PER_EFFECT $-9.08199+0.00137^{*}$ EMPL_20

R_GDP_21 $=-7.26241+$ PER_EFFECT $-9.08199+0.00137^{*}$ EMPL_21

R_GDP_22 $=2.167769+$ PER_EFFECT $-9.08199+0.00137^{*}$ EMPL_22

R_GDP_23 $=-0.024458+$ PER_EFFECT $-9.08199+0.00137^{*}$ EMPL_23

R_GDP_24 $=9.55237+$ PER_EFFECT $-9.08199+0.00137 *$ EMPL_24

R_GDP_25 $=10.41685+$ PER_EFFECT $-9.08199+0.00137^{*}$ EMPL_25

R_GDP_26 $=6.96930+$ PER_EFFECT $-9.08199+0.00137^{*}$ EMPL_26

R_GDP_27 $=4.89565+$ PER_EFFECT $-9.08199+0.00137^{*}$ EMPL_27

R_GDP_28 $=-29.088853+$ PER_EFFECT $-9.08199+0.00137 *$ EMPL_28

The Dynamic Panel and Fixed-Effects Models were utilized to make simulations for 2015-2017. The GDP rates corresponding to each country are aggregated by calculating the mean in order to get the real GDP rate for overall EU-28. In what concerns the employment, the levels registered in 2014 and 2015 are considered in simulations.

Table 3

The real GDP rate in the EU-28 according to simulations over 2016-2017

\begin{tabular}{|c|c|c|}
\hline Model & 2016 & 2017 \\
\hline M1 & 1.78 & 2.2 \\
\hline M2 & 1.97 & 2.33 \\
\hline M4 & 1.96 & 2.03 \\
\hline M6 & 2.04 & 2.1 \\
\hline M7 & 2.01 & 2.23 \\
\hline M8 & 2.3 & 2.44 \\
\hline Fixed-effects model & 2.07 & 2.5 \\
\hline
\end{tabular}

Source: authors' computations. 
The minimum simulated value for real GDP rate in the EU-28 in 2016 was anticipated by M1 model, while the highest value was predicted by M8 model. For 2017, M4 model provided the lowest real GDP rate, while the proposed fixed effects model predicted the highest economic growth.

\section{CONCLUSIONS}

There are a lot of determinants for real GDP rate that are proposed by the economic theory. We take into account that the increase GDP in previous a period with 1 percentage point generated an increase of real GDP in a current period. In addition, the employment rate has an impact to real GDP rate. It can be considered a modification of the well-known Okun's Law. In this study, dynamic panel data models are proposed, because the value of GDP might be determined by the values of the same indicator in previous period. This implies that GDP in a previous period have an impact on the current real GDP. This assumption is supported by results of the tests of the models presented in this study. Not all of them were valid. For the estimation of real GDP for 2016 and 2017 only models, which met the conditions of zero autocorrelation for errors in first difference, were taken into account. On the other hand, a Fixed Effect Model is proposed with individual effects and time effects to explain the GDP rate using 'employment' as an explanatory variable. Several dynamic models analyzed the real GDP growth, an increase in the real GDP rate in the previous period by 1 percentage point determining an increase in the real GDP rate in the actual period by a value between 0.3 percentage points and 0.5 percentage points.

In the introduction of this study we assumed, that the previous real GDP growth and the employment have the impact on the current real GDP rate. Through the analyses conducted on panel data, this assumption was successfully confirmed.

The models are proposed for EU-28 and simulations are made for 2016 and 2017. Higher GDP rates are anticipated for 2016 and 2017 by the Fixed Effect Model compared to dynamic models in the EU-28.

The use of Panel Data Approach based on employment has less skewness, such as the age structure of employers was not taken into account. Presented Panel Data Approach abstracts from other determinants which have an impact of GDP growth. This provides opportunities for future research, where the impact of FDI, or government spending, can be analyzed and the other models can be designed and tested.

In a future study, the real GDP rate can be explained using other independent variables like total investment, general government total expenditure, current account balance, inflation, unemployment rate, general government revenue, gross national savings, population, volume of exports of goods and services, volume of imports of goods and services.

\section{REFERENCES}

Adhikary, B. K., (2011). FDI, trade openness, capital formation, and economic growth in Bangladesh: A lingkage analysis. International Journal of Economics and Finance, 6(1), pp. 16-28.

Barseghyan, L., \& Battaglini, M. (2016). Political economy of debt and growth. Journal of Monetary Economics, 82, 3651. doi:10.1016/j.jmoneco.2016.06.007

Belás, J., Korauš, M., Kombo, F., Korauš, A., (2016). Electronic banking security andcustomer satisfaction in commercial banks. Journal of security and sustainability issues, 3(3), pp. 411-422.

Bratu, M. (2012) Accuracy assessement of short run macroeconomic forecasts in Romania. Economics and Sociology, 5 (1), pp. 26-38. 
Caraiani, P., (2012). Asymmetry in the Okun Coefficient in Romanian Economy. E a M: Ekonomie a Management, 15(4), pp. 49-55.

Carriero, A., Clark, T. E., \& Marcellino, M. (2015). Bayesian VARs: Specification choices and forecast accuracy. Journal of Applied Econometrics, 30(1): 46-73.

Ciccarelli, M., Ortega, E., Valderrama, M.T., (2016). Commonalities and cross-country spillovers in macroeconomicfinancial linkages. The B.E. Journal of Macroeconomics. 16 (1): 231-275.

Ciftcioglu, S. and Begovic, N., (2008). The relationship between economic growth and selected macroeconomic indicators in a group of Central and East European countries: a panel data approach. Problems and Perspectives in Management, 63(1), pp. 24-30.

Cross, J., \& Poon, A. (2016). Forecasting structural change and fat-tailed events in australian macroeconomic variables. Economic Modelling, 58, 34-51. doi:10.1016/j.econmod.2016.04.021

Chubrik, A., (2005). Market Reforms and Economic Growth in Post-Communist Economies: A Panel Data Approach. Policy Document Center, 1(2), pp. 1-6.

Egger, P. and Larch, M., (2007). An assessment of the Europe agreements effects on bilateral trade, GDP, and welfare. European Evconomomic Review, 55(2), pp. 263-279.

Flek, V. and Myslíková, M., (2015). Uneployment Dynamics in Central Europe: A Labour Flow Approach. Prague Economic Papers, 24(1), pp. 73-87.

Furceri, D. and Karras, G., (2008). Tax Changes and Economic Growth: Empirical evidence for a panel of OECD countries. Manuscript, University of Illinois, 1, pp. 1-29.

Higgins, P., Zha, T., \& Zhong, W. (2016). Forecasting china's economic growth and inflation. China Economic Review, 41, pp. 46-61. doi:10.1016/j.chieco.2016.07.011

Hoang, T. T., Wiboonchutikula, P. and Tubtimtong, B., (2010. Does foreign direct investment promote economic growth in Vietnam?. ASEAN Economic Bulletin, 273(2), pp. 295-311.

Hussin, F. and Saidin, N., (2012). Economic Growth in ASEAN-4 Countries: A Panel Data Analysis. International Journal of Economics and Finance, 49(1), pp. 119-127.

Matutinović, I., Salthe, S. N., \& Ulanowicz, R. E. (2016). The mature stage of capitalist development: Models, signs and policy implications. Structural Change and Economic Dynamics, 39, pp. 17-30. doi:10.1016/j.strueco.2016.06.001

Mielcová, E., (2011). Economic Growth and Unemployment Rate of the Transition Country - the Case of the Czech Republic 1996-2009. E a M: Ekonomie a Management, 1/2011, pp. 29-37.

Ono, T., \& Uchida, Y. (2016). Pensions, education, and growth: A positive analysis. Journal of Macroeconomics, 48, 127143. doi:10.1016/j.jmacro.2016.03.005

Patillo, C., Poirson, H. and Ricci, L., (2004). What are the Channels Through Which External Debt Affects Growth?. IMF Working Paper, 0415(1), pp. 1-20.

Petrakos, G., Arvanitidis, P. and Pavleas, S., (2007. Determinants of economic growth: the experts' view. 2nd Workshop of DYNREG in Athens, 2(1), pp. 9-10.

Rodionov, D. G., Guzikova, L. A., \& Rudskaya, I. A. (2014). Innovation potential of regions as a factor of national economy competitiveness. Actual Problems of Economics, 158(8), 215-223.

Tas, N., Hepsen, A. and Onder, E., (2013). Analyzing Macroeconomic Indicators of Economic Growth Using Panel Data. International Conference on Economic and Social Studies, 10-11 May, 2013, Sarajevo, 1(1), International Burch University.

Trpkova, M. and Tashevska, B., (2011). Determinants of economic growth in South-East Europe: A panel data approach. Perspectives of Innovation in Economics and Business PIEB. 7(191), pp. 12-15.

Workie, M., (2005). Determinants of growth and convergence in transitive economies in the 1990s: Empirical evidence from a panel data. Prague Economic Papers. 3(2005), pp.239-51. 